\title{
STUDY ON THE CHARACTERISTICS OF INTERNATIONAL COAL TRADE ON COMPLEX NETWORK
}

\author{
Xiaoci $\mathrm{CHEN}^{1 *}$, Zhanglu TAN ${ }^{2}$, Siwen $\mathrm{LI}^{2}$ \\ ${ }^{1}$ Changzhou University, Changzhou, China \\ ${ }^{2}$ China University of Mining \& Technology, Beijing, Beijing, China \\ Received 20 October 2020; accepted 17 June 2021; first published online 23 February 2022
}

\begin{abstract}
This paper builds a complex network of weighted and directed coal trade based on the international coal trade data in the United Nations trade database from 1999 to 2018, specifically analyzes the trade scale, trade relations, and trade distribution and other characteristics of international coal trade, and determines the main trade core countries and trade hub countries. The results show that the scale of international coal trade has grown steadily, but the transformation of trade relations is complicated. Especially in the context of increasing trade frictions, trade links between countries have decreased significantly, trade balance has declined, and trade agglomeration has increased. Australia, the United States, Japan and other countries are big coal trading countries, while the United States, South Africa, India and other countries are important trading hubs. Based on the theory of competitive advantage, this paper proposes corresponding countermeasures for different countries to enhance their competitive advantages.
\end{abstract}

Keywords: international coal trade, complex network, trade scale, trade relations, trade distribution, trade core countries, trade hub countries.

JEL Classification: F02, F14, F23.

\section{Introduction}

In recent years, international trade conflicts have become increasingly fierce. Energy products, as an important guarantee for technological progress and national development, are not immune. Economy and trade are inseparable (Hye \& Lau, 2015). Only by deeply understanding the evolutionary characteristics of international commodity trade can we accurately grasp the development trend of commodity trade in various countries. Taking coal trade as an example, this paper studies the evolution characteristics of international coal trade from the aspects of trade scale, trade flow and major trade participating countries, and provides important prior knowledge for relevant trade participating countries to gain competitive advantages and formulate trade policies.

*Corresponding author. E-mail: nb.chenxc@qq.com

Copyright (c) 2022 The Author(s). Published by Vilnius Gediminas Technical University

This is an Open Access article distributed under the terms of the Creative Commons Attribution License (http://creativecommons. org/licenses/by/4.0/), which permits unrestricted use, distribution, and reproduction in any medium, provided the original author and source are credited. 
Among the natural resources, what is striking is that energy resources notably impact the economy, the industry, the population, the education and other fields (Torres et al., 2013). This matters more in the developing countries with fast economic growth, such as China (Umar et al., 2020). The coal is known as a typical energy product, and it is also an important national strategic resource. According to the BP Statistical Review of World Energy 2019, global coal production grew by 4.3 percent year on year in 2019, twice the average growth rate of the last decade, and coal accounted for 27.2 percent in the global primary energy in 2018, more than 50 percent in the primary energy of developing countries, including China (BP, 2019). In the current environment, studying the characteristics of international coal trade is of great significance for stabilizing the market, formulating competitive strategies, and promoting global economic growth.

This paper aims to establish a quantitative and systematic theoretical model for analyzing the characteristics of international coal trade, systematically studies the characteristics of the international coal trade, analyzes its competition in the international market, and ultimately guide countries to form a competitive advantage strategy. This paper not only has certain theoretical significance, but also has considerable practical value.

The paper is structured as follows. Section 1 explains the theoretical background of the research and the reasons for selecting the research method. Section 2 constructs the theoretical model and the network model of coal trade, also shows the data source, the applicability of the method and the calculation formula of the index. Section 3 presents the results. Section 4 shows the countermeasures. The final section concludes the paper.

\section{Literature review}

It is well known that the coal is one of the most widely used primary energy sources in the world. Many researchers have made various economic models from policy, environment, finance and other aspects to study the characteristics of coal trade in depth. Chen J analyzes the influence of BRICs in energy trade, and finds that in the coal trade among BRICS countries, China's competitiveness is declining annually while Russia shows an opposite trend (Chen et al., 2021). Hauenstein and Holz (2021) analyzes the future role development of the U.S. coal industry from an industry perspective. Guan and An (2017) took four of the primary energy products as the research objects to discuss the energy trade preferences of the world's major energy consuming countries, and argued that governments can develop traditional energy trade through more triangular cooperation. Wu and Chen (2018) used a multi-regional input-output model to track the consumption and use of raw coal in the world, and concluded that the United States and China have important influences in the world coal trade. Furthermore, Xia et al. (2017) established a multi-regional input-output model to find the central hub in the coal supply chain, and determined the key role of direct trade in the global coal utilization of the United States, China and other economic powers. In view of the current phenomena that the environmental protection policy by reducing coal consumption universally caters to the demand side, Gao et al. (2018) proposed to remove production subsidies and suspend the development of new coal mines, which could reduce the quantum of international coal trade and achieve the energy-saving and emission reduction. 
The above studies have specifically examined one or more impact factors in coal trade, analyzed its local characteristics and time evolution, and put forward specific suggestions to improve competitive position. However, these researches do not study the characteristics of coal trade thoroughly and systematically. In recent years, the complex network researches have gradually emerged and extended from the computer field to other disciplines, thus the establishment of various trades networks and transportation networks provide brand new ideas for related researches (Barabási \& Albert, 1999). Hu et al. (2020) constructed a global scrap metal trade network to analyze the characteristics and dynamic evolution of the scrap metal trade. Zhong et al. (2018) established a complex network of international steel trade and found that global steel trade is increasingly concentrated in a few countries, and the trade hierarchy is becoming increasingly obvious. On the basis of the multi-regional input-output model and complex network, Wang et al. (2019) built the global rare earth flow complex networks, revealed the community distribution in rare earth trade, and identified the three most important trading entities: China, the United States, and Germany. Long et al. (2019) selected global forest products trade data from 2004 to 2016 to build a complex network and confirmed that the United States takes the core position in the trade competitions. Malighetti et al. (2019) explored the evolution of Asian aviation networks in the new era, arguing that more cooperative and free policy measures are conducive to improving the efficiency of air transportation. Zhong et al. (2017) et al. used quantitative analysis of community evolution to detect cluster changes in the centralized trade of fossil fuel countries such as oil and natural gas. The above-mentioned research is of great significance to the promotion and application of complex networks and related research.

The international coal trade network is a typical complex system involving many countries, the trade relations between countries are changing dynamically, and the complex network method has already been the extensive application in the coal transportation and coal price analysis, showing its strong suitability (Bhattacharya et al., 2008; Guan \& An, 2017; Xia et al., 2017; Wang et al., 2019; Wang \& Li, 2019; Zhang et al., 2019; Semanur et al., 2020). In the global trade system, what should be of concern is that how the system changes and the change characteristics of its members. The changes of these crucial members have an important effect on the whole system. Other impacted members need to improve their capacity of avoiding adverse impact and develop their foreseeability of good news. The coal trade system is a typical complex network with numerous members, where trade relations are under dynamic changing (Cronshaw, 2015). In the process of building international coal trade complex networks, the trade participants can be abstracted into individual nodes, and the connections between nodes can be used to represent trade transactions. Based on this, the complex trading system can be mapped into an abstract network. Having built the coal international trade networks, researchers can systematically analyze the trade volume, node degree, node strength, centrality, clustering coefficient, network density, average path length and other indicators. By analyzing these changing indicators over time and summarizing the changing characteristics, researchers can confirm the primary trade participants and their importance in the process, and specify the development and change of the international coal trade throughout the previous period. The changes of the overall indexes can reflect whether the international coal trade tends to be rather conservative or not. The indexes from the 
nodes can present the trade tendencies of the major coal trading countries. After the trade disputes, its trade restorability is also noteworthy for researchers. These changes in reality can be abstracted to be the changes of the network indicators.

This paper takes the international coal trade as its research object. Based on the theory of international trade and complex networks, without consideration of geographic location and environmental differences, each trading country is abstracted as a node and the trade relations between countries are abstracted as edges. It constructs unweighteddirect and weighted-direct international coal trade complex networks. The complex networks are constructed from the perspectives of trade scale, trade relations, trade flows and core trade participants to study the characteristics of the international coal trade. It finally proposes strategies for countries to gain competitive advantages in the international coal trade.

\section{Methodology and data}

This study selects 1999-2018 international coal (Customs Code: HS2701, coal) trade data in the United Nations commodity trade statistics database (http://comtrade.un.org). The international coal trade complex networks can be built as $G=(V, E, W)$, where $V=\left\{v_{1}, v_{2}, \ldots, v_{N}\right\}$ represents the set of countries, $E=\left\{e_{1}, e_{2}, \ldots, e_{S}\right\}$ represents the set of coal trade links between all countries, $W=\left\{w_{1}, w, \ldots, w_{T}\right\}$ represents the set of trade volume, and $N$ represents the number of these countries. The trade network can be expressed in matrix form and the unweighted-direct network is as follows:

$$
G_{N \times N}=\left\{\begin{array}{ccc}
e_{11} & \cdots & e_{1 N} \\
\vdots & \ddots & \vdots \\
e_{N 1} & \cdots & e_{N N}
\end{array}\right\},
$$

where $e_{i j}=0$ means no link between the country $i$ and the country $j$.

The weighted-direct network is as follows:

$$
G_{N \times N}=\left\{\begin{array}{ccc}
w_{11} & \cdots & w_{1 N} \\
\vdots & \ddots & \vdots \\
w_{N 1} & \cdots & w_{N N}
\end{array}\right\},
$$

where $w_{i j}$ represents the trade volume between the country $i$ and the country $j$.

The complex networks refer to the networks with some or all characteristics such as "small world", "cluster" and "power-law degree distribution" (Watts \& Strogatz, 1998; Barabási \& Albert, 1999). The international coal trade network is characterized by "small world" and "cluster". As shown in Figure 1, the degree distribution basically conforms to the power-law distribution. Therefore, the international coal network is exactly a typical one, which can be analyzed by the theory of complex network.

This paper analyzes the international coal trade complex network from the aspects of network density, network diameter, node degree and degree relationship (Strogatz, 2001; Newman, 2002; Guimera et al., 2005). 

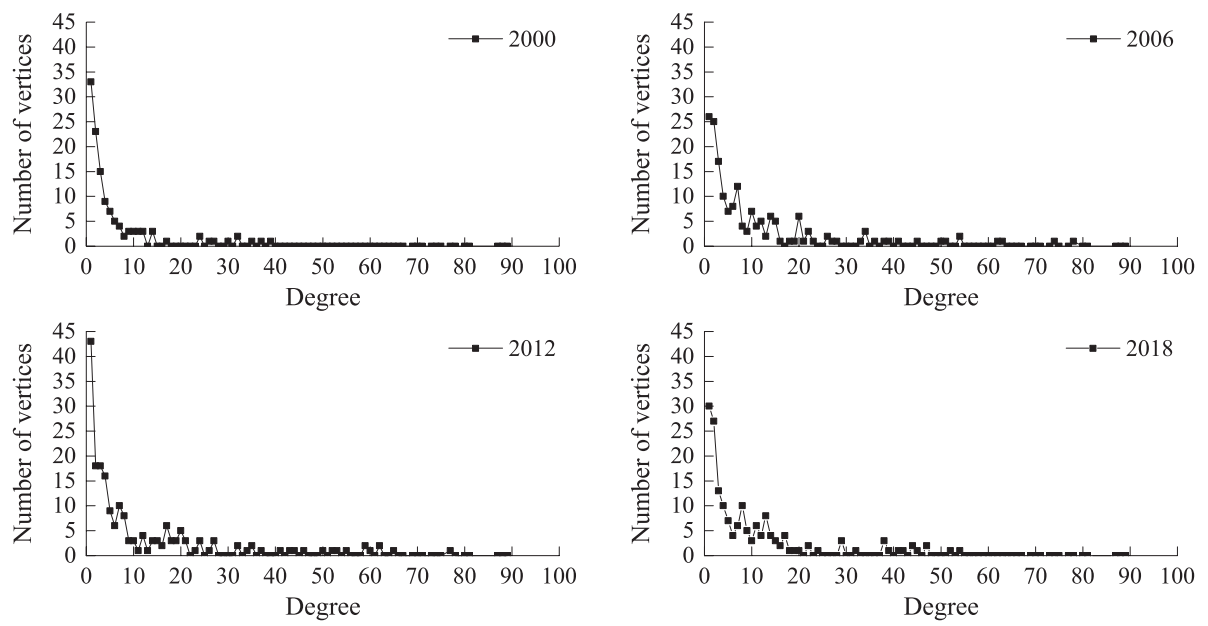

Figure 1. Degree distribution in 2002, 2006, 2010, 2014 and 2018

The network density describes the density of connections between nodes in a network. Suppose the number of countries participating in international coal trade is $N$, the actual number of connections is $M$, and the calculation formula for network density is as follows:

$$
\text { Density }=\frac{M}{N(N-1)} .
$$

The average path length (APL) is the average of the number of edges that the shortest path passes between the nodes in the network. Let $d_{i j}$ be the number of edges passed by the shortest path between node $i$ and node $j$, the calculation formula of the average path length is as follows:

$$
\text { Length }=\frac{1}{N(N-1)} \sum_{i \neq j} d_{i j} .
$$

The network diameter is the maximum number of edges that the shortest path passes between the nodes in the network which reflects the degree of trade risk. The calculation formula of the Network Diameter is as follows:

$$
\text { Diameter }=\max \left(d_{i j}\right) \text {. }
$$

The Standard network strength entropy (SNSE) defines the non-homogeneity of a complex network. Let $k_{i}$ be the degree centrality of the node, and the calculation formula of SNSE is as follows:

$$
\text { Entropy }=\frac{-2 \sum_{i=1}^{N}\left(\frac{k_{i}}{\sum_{i=1}^{N} k_{i}} \ln \frac{k_{i}}{\sum_{i=1}^{N} k_{i}}\right)-\ln 4(N-1)}{\ln N^{2}-\ln 4(N-1)} .
$$

The degree centrality measures the number of points with directly connection to the nodes in the network. The calculation formula for the degree centrality of nodes is as follows: 


$$
\text { Degree Centrality }=\sum_{i \neq j} e_{i j} \text {. }
$$

The betweenness centrality describes the degree of node control over resources in the network. Assuming that the number of paths between node $j$ and node $k$ in the network is $g_{j k}$, the number of paths passing through the node $i$ is $g_{j k}(i)$, and the definition is $b_{j k}(i)=\frac{g_{j k}(i)}{g_{j k}}$. In order to compare complex networks of different sizes, the calculation formula for the betweenness centrality of nodes is as follows:

$$
\text { Betweeness Centrality }=\frac{2 \sum_{j}^{n} \sum_{k}^{n} b_{j k}(i)}{N^{2}-3 N+2} .
$$

The degree assortativity coefficient is used to measure the connection tendency of nodes, reflecting the trade tendency of trading countries. Supposing there is an adjacency matrix, each element in the matrix is $c_{i j}$, let $\sum_{i j} c_{i j}=1, \sum_{j} c_{i j}=a_{i}, \sum_{i} c_{i j}=b_{i}$, the calculation formula of the degree assortativity coefficient is as follows:

$$
\text { Degree Correlation }=\frac{\sum_{i} c_{i i}-\sum_{i} a_{i} b_{i}}{1-\sum_{i} a_{i} b_{i}} .
$$

The clustering coefficient (Clustering) is the average probability of interconnection between two nodes connected to the same node in the network, reflects the degree of aggregation of trade relations and trade networks. Suppose a node $i$ has $N_{i}$ adjacent nodes, the actual number of connections between those nodes is $M_{i}$, and the calculation formula of the clustering coefficient is as follows:

$$
\text { Clustering }=\frac{2 M_{i}}{N_{i}\left(N_{i}-1\right)}
$$

The reciprocity is used to measure the degree of interconnection between nodes in the network and reflects the amount of two-way trade in trade relations. Suppose $\bar{e}=\sum_{i \neq j} \frac{e_{i j}}{N(N-1)}$, the calculation formula of the reciprocity coefficient is as follows:

$$
\text { Reciprocity }=\frac{\sum_{i \neq j}\left(e_{i j}-\bar{e}\right)\left(e_{j i}-\bar{e}\right)}{\sum_{i \neq j}\left(e_{i j}-\bar{e}\right)^{2}} .
$$

\section{Results}

\subsection{Analysis of the overall pattern of trade}

Analysis of international coal trade volume and trade value: Through the analysis of the participating countries, trade relations, trade amount and trade volume of international coal trade from 1999 to 2018, the overall characteristics of international coal trade can be found. 
As shown in the Figure 2, from the perspective of trade volume, the scale of the international coal trade increased steadily from 1999 to 2007. It fell slightly in 2008, and then continued to grow. There were slight fluctuations in 2013-2017, and the growth rate in 2017-2018 was significantly accelerated. From the perspective of total trade amount, the scale of coal trade grew rapidly from 1999 to 2008, and fell slightly from 2008 to 2009, and then continued to grow, and reached its peak in 2011. The scale of international coal trade dropped sharply since 2011. It bottomed out in 2016 and rebounded and has maintained steady growth so far.

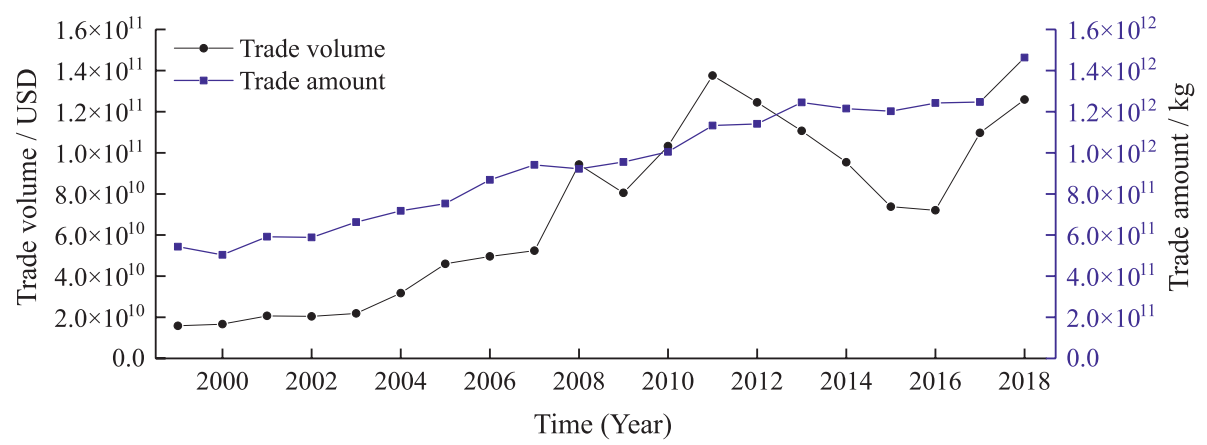

Figure 2. Changes in the coal trade from 1999 to 2018

Analysis on the Main Body of International Coal Trade and Trade Relations: With the development of the economy and the increasing demand for human energy, although oil, natural gas, solar, wind and other energy sources are becoming more abundant, many countries still participate in the coal trade. As an important primary energy source, the coal is still inseparable for human production and life for a long period of time. However, due to the more and more alternative energy sources, it is an irreversible trend that the coal transactions tend to proceed steadily or even suffer a downtrend. As Figure 3 shows, the number of participating countries in coal trade has fluctuated and increased since 2001, decreased slightly between 2008 and 2009, and finally reached a peak in 2012, and then slowly declined. The number of coal trade relations fluctuated upwards, and reached a peak in 2016, decreased sharply from 2016 to 2017, and remained stable in 2018. Similarly, the changes in the quan-

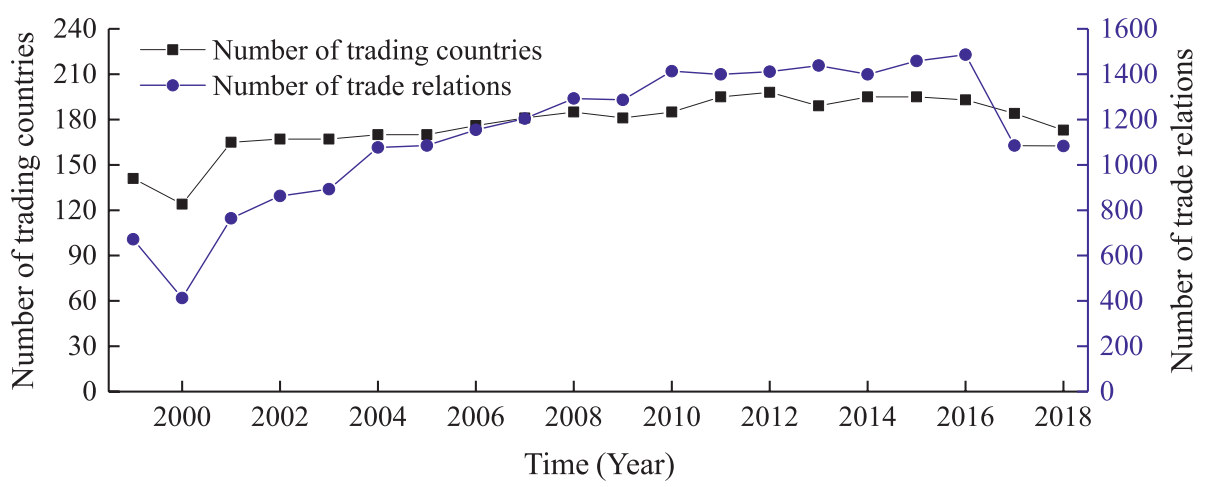

Figure 3. Trends in the total international trade of coal 
tity of coal importing and exporting countries in Figure 4 also support the changes in trade relations basically corresponding to those in the Figure 3. The activeness of the international coal trade tends to be a slowdown, which probably continues for some time to come.

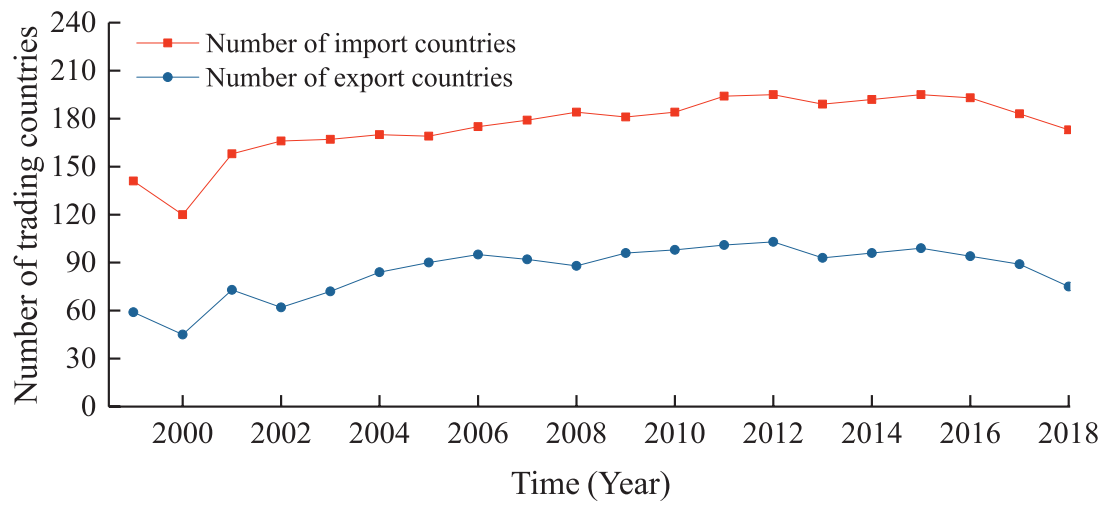

Figure 4. Evolution of the number of trading countries

\subsection{Evolution of coal trade relations}

Changes in trade relations are an important part of the evolution of coal trade. Through the analysis of the scale of coal trade and trade relations, it is found that the importance of coal has increased relatively, trade relations have increased steadily, and the trade system has become more and more complex.

Evolution of the tightness of the coal trade links: Through the evolution analysis of network density, network diameter and average path length based on the unweighted-direct coal trade network from 1999 to 2018, the overall tightness of the international coal trade is measured.

From Table 1, the network density rises with fluctuations and the network diameter remains basically stable. For a long time, the diameter of the coal trade network has been in the range [6,7], which indicates that there exists high risk in the coal trade. In addition, the average path length of the network is greater than 2 from 1999 to 2018 , which shows that the cost of the coal circulation is high. The evolution of the trade intimacy reveals that the international coal trade is getting closer, but there always exists a high trade risk. A higher level of risk is not conducive to the stability of the coal trade and restricts closer exchanges at the same time.

The evolution of trade relevance: The study calculated the changes in the clustering coefficient of the international coal trade network from 1999 to 2018. The specific analysis is made from the four angles of degree distribution, clustering coefficient difference of the same degree value, clustering coefficient change at the same time, and clustering coefficient distribution. As shown in the Figure 5, the degree distribution is relatively scattered, with the maximum degree value exceeding 70 throughout the years. As time grows, the degree of nodes in the network increases, indicating that the entire coal trade network is more complex. Under the premise of consistent centrality, the clustering coefficient of nodes fluctuates 
Table 1. 1999-2018 International coal trade indicators

\begin{tabular}{|l|c|c|c|c|c|c|c|}
\hline Year & $\begin{array}{c}\text { Network } \\
\text { density }\end{array}$ & $\begin{array}{c}\text { Network } \\
\text { diameter }\end{array}$ & $\begin{array}{c}\text { Average } \\
\text { path length }\end{array}$ & Year & $\begin{array}{c}\text { Network } \\
\text { density }\end{array}$ & $\begin{array}{c}\text { Network } \\
\text { diameter }\end{array}$ & $\begin{array}{c}\text { Average } \\
\text { path length }\end{array}$ \\
\hline 1999 & 0.0113 & 6 & 2.77 & 2009 & 0.0217 & 6 & 2.62 \\
\hline 2000 & 0.00697 & 7 & 2.69 & 2010 & 0.0238 & 6 & 2.54 \\
\hline 2001 & 0.0129 & 7 & 2.65 & 2011 & 0.0236 & 6 & 2.57 \\
\hline 2002 & 0.0146 & 6 & 2.55 & 2012 & 0.0238 & 7 & 2.62 \\
\hline 2003 & 0.0151 & 6 & 2.71 & 2013 & 0.0243 & 6 & 2.48 \\
\hline 2004 & 0.0182 & 6 & 2.64 & 2014 & 0.0236 & 6 & 2.47 \\
\hline 2005 & 0.0183 & 6 & 2.80 & 2015 & 0.0246 & 7 & 2.59 \\
\hline 2006 & 0.0195 & 6 & 2.63 & 2016 & 0.0251 & 7 & 2.45 \\
\hline 2007 & 0.0203 & 6 & 2.58 & 2017 & 0.0183 & 6 & 2.69 \\
\hline 2008 & 0.0218 & 6 & 2.51 & 2018 & 0.0183 & 6 & 2.62 \\
\hline
\end{tabular}

and rises over time, indicating that the agglomeration degree of international coal trade is constantly changing, and nodes with larger clustering coefficients often have lower centrality.

Combined with Table 2 and Table 3, taking 2018 as an example, countries with a higher clustering coefficient often have fewer trade partners, and these countries have less trade, and their imports are basically greater than their exports, indicating that these countries have little demand for coal. Meanwhile, due to the constraints of economic level, transportation conditions, and resource endowment, countries only trade with a few specific countries, so they have a high degree of relevance. Countries with high degree centrality always have low agglomeration levels due to a large number of trading partners and the varying levels of economic development and geographic distribution of their trading partners. From the distribution of clustering coefficient, the international coal trade has undergone a process from order to disorder, and then to order. Overall, the clustering coefficient's distribution from 2008 to 2011 is significantly more chaotic. Prior to this, there were fewer coal trade relationships in the early stages. After that, the coal trade gradually increased, and some more obvious trade groups began to appear.

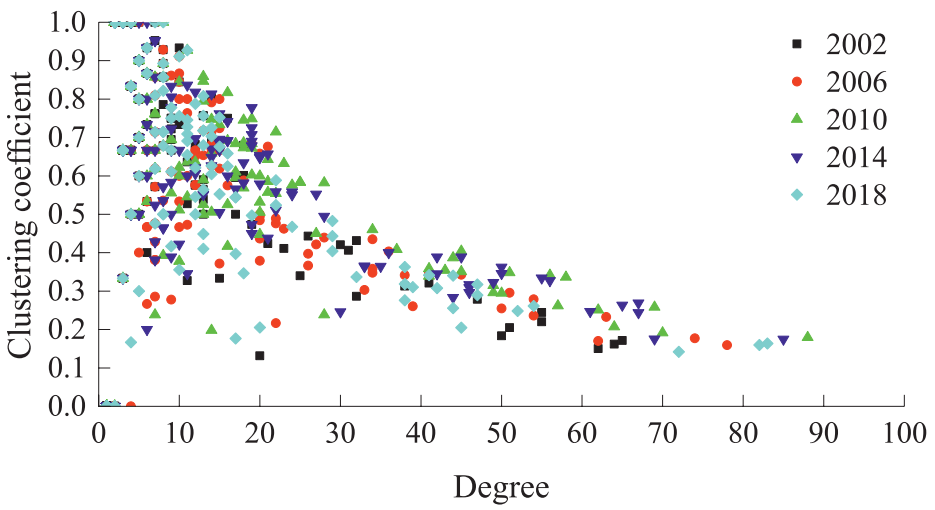

Figure 5. Cluster coefficient evolution in 2002, 2006, 2010, 2014 and 2018 
Table 2. Ten countries with higher clustering degree in 2018

\begin{tabular}{|c|c|c|c|c|}
\hline Country & $\begin{array}{c}\text { Number of import } \\
\text { countries }\end{array}$ & $\begin{array}{c}\text { Number of export } \\
\text { countries }\end{array}$ & Trade amount/Kg & $\begin{array}{c}\text { Clustering } \\
\text { coefficient }\end{array}$ \\
\hline AM & 2 & 0 & $1.92 \times 10^{6}$ & 1 \\
\hline BJ & 3 & 0 & $1.20 \times 10^{8}$ & 1 \\
\hline SV & 2 & 0 & $2.31 \times 10^{6}$ & 1 \\
\hline NI & 2 & 0 & $3.45 \times 10^{3}$ & 1 \\
\hline PY & 3 & 0 & $4.38 \times 10^{6}$ & 1 \\
\hline BN & 7 & 2 & $1.52 \times 10^{7}$ & 0.95 \\
\hline LU & 9 & 3 & $5.11 \times 10^{7}$ & 0.95 \\
\hline MT & 4 & 1 & $1.64 \times 10^{4}$ & 0.93 \\
\hline KH & 5 & 1 & $5.07 \times 10^{7}$ & 0.92 \\
\hline PY & 8 & 0 & $4.55 \times 10^{8}$ & 0.92 \\
\hline
\end{tabular}

Table 3. Ten countries with lower clustering degree in 2018

\begin{tabular}{|c|c|c|c|c|}
\hline Country & $\begin{array}{c}\text { Number of import } \\
\text { countries }\end{array}$ & $\begin{array}{c}\text { Number of export } \\
\text { countries }\end{array}$ & Trade amount/kg & $\begin{array}{c}\text { Clustering } \\
\text { coefficient }\end{array}$ \\
\hline ZA & 37 & 72 & $8.44 \times 10^{10}$ & 0.14 \\
\hline US & 17 & 81 & $1.47 \times 10^{11}$ & 0.16 \\
\hline RU & 15 & 83 & $2.22 \times 10^{11}$ & 0.16 \\
\hline GH & 9 & 1 & $5.36 \times 10^{7}$ & 0.17 \\
\hline LB & 5 & 11 & $7.81 \times 10^{7}$ & 0.18 \\
\hline TR & 13 & 35 & $3.83 \times 10^{11}$ & 0.21 \\
\hline PE & 4 & 18 & $9.51 \times 10^{8}$ & 0.21 \\
\hline UK & 27 & 46 & $1.01 \times 10^{10}$ & 0.245 \\
\hline CN & 28 & 35 & $1.91 \times 10^{11}$ & 0.26 \\
\hline NL & 43 & 48 & $2.77 \times 10^{10}$ & 0.26 \\
\hline
\end{tabular}

Evolution of the relevance of trading countries: In order to determine whether the participating countries of the international coal trade tend to trade with countries which possess comparable centrality, the degree assortativity coefficients for the period of 1999 to 2018 are needed to be calculated. As shown in the Figure 6, except in 2000, the degree assortativity coefficients of international coal trading networks are all less than 0 , which is a typical heterogeneous mixture. On the whole, the degree assortativity coefficient of coal trade is decreasing, which indicates that countries with less centrality degree tend to trade with countries with greater centrality degree in the coal trade. For one thing, the country with higher centrality degree always means it has more trading partners and can provide better products. For another, countries with a higher centrality degree are more geographically dispersed. They generally assume the role of trade hub and information core, with more resources at their disposal. So they are more inclined to trade with them, and this trend is becoming increasingly clear. 


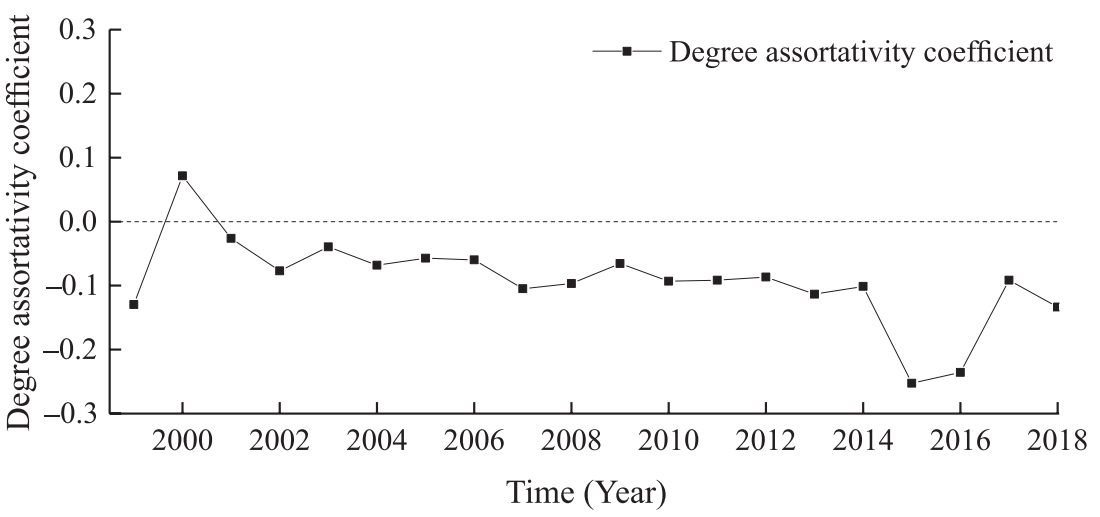

Figure 6. Evolution of node degree assortativity coefficient from 1999 to 2018

Evolution of market trade's order: The evolution of the international coal trade order is analyzed from the two aspects, respectively the convenience and order of trade. As shown in Table 1, the average path length of the network is less than 3, reaching the minimum value of 2.45 in 2016. This shows that with the deepening of the international coal trade, connections between countries have become more convenient. Figure 7 shows that the reciprocal coefficients of the international coal trade are between 0.20 and 0.35 , which is lower than 0.5 , indicating that the order of the international coal trade network is not high, bilateral trade between countries is relatively small, and most countries have obvious import or export advantages. Before 2010, the reciprocity coefficients show a clear upward trend of volatility, but it began to fall significantly after 2010. It shows that despite the increasing frequency of bilateral trade, the orderliness of the coal trade network still needs to be improved, while the complementarity of the national trade between countries tends to diminish, and regional monopoly groups are most likely to be formed.

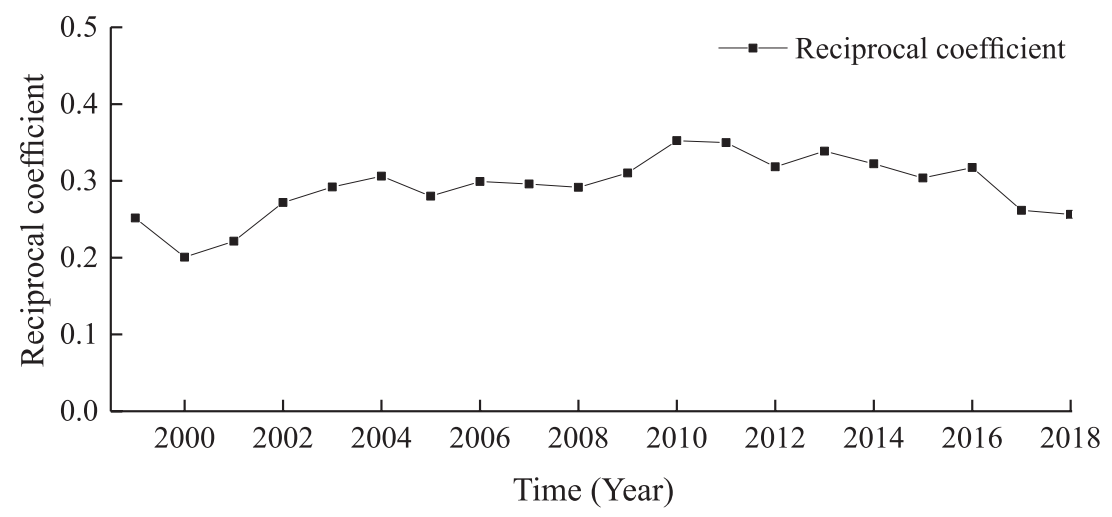

Figure 7. Reciprocal coefficients curve from 1999 to 2018

The above results indicate that the international coal trade is still at high risk and the monopolistic organizations in a growing market are emerging. That the coal trade is growing more concentrated is advantageous to large countries of coal trading, especially large import- 
ers. However, for small and medium-size countries, it is indispensable to maintain sharp vigilance about forming the monopoly body, and changing energy structure and developing multilateral trade are their viable options. For a coal importer, it is inevitable to find alternative energy sources or more coal suppliers. For a coal exporter, expanding production and global energy acquisition is conducive to further consolidating its position.

\subsection{Evolution of trade flows of coal}

The analysis of the trade relations is mainly to reveal the characteristics of trade networks from the perspective of the connectivity of vertices in the international coal trade network. The trade volume between countries may differ sharply, but the analysis of the network topology ignores this difference. Therefore, the standard network strength entropy is used as a primary metric index to study the evolution of coal trade flow distribution.

Evolution of the coal trade equilibrium: As shown in Figure 8, the standard network strength entropy of the coal trade network is less than 0.7 over the years, indicating that the trades between countries had been generally unbalanced. The standard network strength entropy of the network went through a process of increasing at the early stage and then decreasing where it reached its peak in 2006. Before 2006, the heterogeneity of the network had declined, and the trade gap between countries had gradually dwindled. However, after 2006 the standard network strength entropy of the network fluctuated downward and the trade gap between countries widened, which manifests the fact that only a few countries owned a large trade volume while most countries made up a small proportion. The following reasons have changed the coal trade layout. Firstly, the external demand for energy in the world has increased, and emerging energy importing countries have established trade relations with traditional energy exporting countries. Secondly, constrained by factors such as resources and environment, some countries have reduced or even completely abandoned their external demand for coal, thereby reducing trade with related countries. Finally, political factors increase the cost and risk of the import and export trade, which prompts some countries to shift their trade partners or seek more internal substitution.

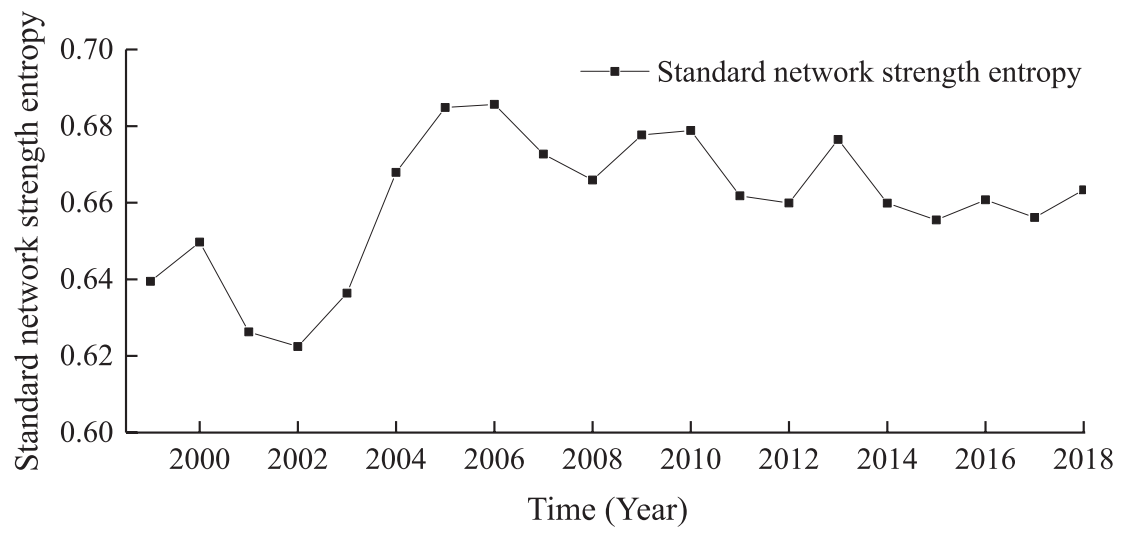

Figure 8. Standard network strength entropy changes from 1999 to 2018 


\subsection{Evolution of the coal trade participating countries}

Evolution of trade influence in major countries: The coal trade influence can be reflected in the total coal trade volume involved in each country, that is, the strength of the nodes in the trade network can be measured by the trade influence index. The international coal trade network is a directed network where the node strength can be divided into the input strength $s^{\text {in }}$ and the output strength $s^{\text {out }}$ according to the direction of trade flows. The node strength is the sum of $s^{\text {in }}$ and $s^{\text {out }}$. First, the trade influence index of a country with the largest trade volume is set as 100 , and the trade impact index of other countries is calculated based on the proportion of their trade volume to the country with the largest trade volume, thereby the trade influence index for each country every year can be obtained. Through the above processing way, the influence index of each country is summarized in the range $[0,100]$, which not only eliminates the magnitude difference of node strength in different years, but also demonstrates the relationship between the node strength and the maximum node strength of each country in the current year. Table 4 shows the top 10 countries of the 1999-2018 trade influence index.

As shown in Table 4, the influence index of net coal exporters is significantly higher than that of net coal importers. Australia, the United States, and Canada are all traditional coal exporting countries. China, Japan and South Korea have strong influence among net coal importing countries. China has been a net coal importer since 2009, and was previously a net coal exporter. Australia has been the country with the largest influence index since 1999 and is significantly ahead of the second ranked country. The main reasons are as follows. First, there exist a large number of opencast coal mines in Australia with the high quality of the coal and the low cost of mining. Second, Australia's coal mining technology is advanced, which not only has extremely high production efficiency, but also has extremely high safety. Australia is a typical coal exporter, and its out-degree is greater than the in-degree. Although Australia has advantages in coal exports, there exist still trade risks that it may be controlled by the coal exporters which have relatively large trade volume with Australia. Furthermore, those countries, such as China, Japan, the United States, Russia, Indonesia and other countries have all exceeded 40 in a certain period of time, but most of them are not stable, and the trade influence index fluctuates greatly. Combined with Figure 9, it can be found that the trade indexes are of a marked difference in distribution and unevenly distributed. A leading trade country must not only have a high trade influence index, but also have a certain degree of stability. From Table 4, the seven countries, including Australia, China, Japan, the United States, Russia, India, and South Korea, have stabilized and ranked high in the trade influence index since 2009. Therefore, these countries are identified as leading countries in the international coal trade.

It can also be seen from Figure 9 that Australia has always had the strongest trade influence, and there will be no major fluctuations in the foreseeable future. Japan's trade influence indexes are relatively stable with a slightly downward trend in general. China's trade influence index reached its peak in 2013, surpassing Japan to become the second most influential country. India's influence index is showing an upward trend, which fits its rapidly developing national strength. The changes in other countries are relatively stable, although there are fluctuations but the magnitude is very small. What is noteworthy is that although Indonesia 
can not be identified as a leading trade country according to the criteria of this paper, its trade influence has grown rapidly in recent years. As the world's second largest coal exporter only after Australia, Indonesia’s trade influence and future development potential can not be underestimated.

Table 4. Trade influence index in 1999-2018

\begin{tabular}{|c|c|c|c|c|c|c|c|c|c|c|}
\hline & 1999 & 2000 & 2001 & 2002 & 2003 & 2004 & 2005 & 2006 & 2007 & 2008 \\
\hline 1 & $\begin{array}{c}\mathrm{AU} \\
(100)\end{array}$ & $\begin{array}{c}\mathrm{AU} \\
(100)\end{array}$ & $\begin{array}{c}\mathrm{AU} \\
(100)\end{array}$ & $\begin{array}{c}\mathrm{AU} \\
(100)\end{array}$ & $\begin{array}{c}\mathrm{AU} \\
(100)\end{array}$ & $\begin{array}{c}\mathrm{AU} \\
(100)\end{array}$ & $\begin{array}{c}\mathrm{AU} \\
(100)\end{array}$ & $\begin{array}{c}\mathrm{AU} \\
(100)\end{array}$ & $\begin{array}{c}\mathrm{AU} \\
(100)\end{array}$ & $\begin{array}{c}\mathrm{AU} \\
(100)\end{array}$ \\
\hline 2 & $\begin{array}{c}\mathrm{JP} \\
(77.36)\end{array}$ & $\begin{array}{c}J P \\
(69.81)\end{array}$ & $\begin{array}{c}\mathrm{JP} \\
(76.78)\end{array}$ & $\begin{array}{c}\mathrm{JP} \\
(79.87)\end{array}$ & $\begin{array}{c}\mathrm{JP} \\
(80.25)\end{array}$ & $\begin{array}{c}\mathrm{CN} \\
(84.38)\end{array}$ & $\begin{array}{c}\mathrm{JP} \\
(66.47)\end{array}$ & $\begin{array}{c}\mathrm{JP} \\
(62.5)\end{array}$ & $\begin{array}{c}\mathrm{JP} \\
(65.14)\end{array}$ & $\begin{array}{c}\text { JP } \\
(60.51)\end{array}$ \\
\hline 3 & $\begin{array}{c}\text { US } \\
(44.23)\end{array}$ & $\begin{array}{c}\mathrm{CN} \\
(28.33)\end{array}$ & $\begin{array}{c}\mathrm{CN} \\
(42.57)\end{array}$ & $\begin{array}{c}\mathrm{CN} \\
(50.72)\end{array}$ & $\begin{array}{c}\mathrm{CN} \\
(64.42)\end{array}$ & $\begin{array}{c}\mathrm{JP} \\
(81.85)\end{array}$ & $\begin{array}{c}\mathrm{CN} \\
(45.27)\end{array}$ & $\begin{array}{c}\mathrm{CN} \\
(38.98)\end{array}$ & $\begin{array}{c}\mathrm{CN} \\
(42.86)\end{array}$ & $\begin{array}{c}\mathrm{CN} \\
(31.65)\end{array}$ \\
\hline 4 & $\begin{array}{c}\mathrm{CA} \\
(35.4)\end{array}$ & $\begin{array}{l}\text { KR } \\
(25)\end{array}$ & $\begin{array}{c}\text { US } \\
(38.24)\end{array}$ & $\begin{array}{c}\text { US } \\
(36.23)\end{array}$ & $\begin{array}{c}\text { US } \\
(37.46)\end{array}$ & $\begin{array}{c}\text { US } \\
(43.95)\end{array}$ & $\begin{array}{c}\text { US } \\
(30.72)\end{array}$ & $\begin{array}{c}\text { US } \\
(32.44)\end{array}$ & $\begin{array}{c}\mathrm{RU} \\
(35.89)\end{array}$ & $\begin{array}{c}\text { US } \\
(28.35)\end{array}$ \\
\hline 5 & $\begin{array}{c}\text { KR } \\
(27.99)\end{array}$ & $\begin{array}{c}\text { ID } \\
(24.07)\end{array}$ & $\begin{array}{c}\text { ZA } \\
(28.64)\end{array}$ & $\begin{array}{c}\mathrm{ZA} \\
(30.60)\end{array}$ & $\begin{array}{c}\mathrm{RU} \\
(30.25)\end{array}$ & $\begin{array}{c}\mathrm{RU} \\
(35.48)\end{array}$ & $\begin{array}{c}\mathrm{RU} \\
(27.43)\end{array}$ & $\begin{array}{c}\mathrm{RU} \\
(28.13)\end{array}$ & $\begin{array}{c}\text { US } \\
(35.26)\end{array}$ & $\begin{array}{c}\mathrm{RU} \\
(23.47)\end{array}$ \\
\hline 6 & \begin{tabular}{|c|} 
ID \\
$(24.15)$
\end{tabular} & $\begin{array}{c}\text { CA } \\
(22.22)\end{array}$ & $\begin{array}{c}\text { CA } \\
(28.32)\end{array}$ & $\begin{array}{c}\text { CA } \\
(28.82)\end{array}$ & $\begin{array}{c}\mathrm{ZA} \\
(30.21)\end{array}$ & $\begin{array}{c}\mathrm{KR} \\
(29.94)\end{array}$ & $\begin{array}{c}\mathrm{KR} \\
(24.31)\end{array}$ & $\begin{array}{c}\text { CA } \\
(23.3)\end{array}$ & $\begin{array}{c}\mathrm{NL} \\
(24.97)\end{array}$ & $\begin{array}{c}\mathrm{KR} \\
(22.61)\end{array}$ \\
\hline 7 & $\begin{array}{c}\mathrm{CN} \\
(21.75)\end{array}$ & $\begin{array}{c}\mathrm{CO} \\
(16.19)\end{array}$ & $\begin{array}{c}\text { KR } \\
(27.86)\end{array}$ & $\begin{array}{c}\mathrm{KR} \\
(26.89)\end{array}$ & $\begin{array}{c}\mathrm{KR} \\
(28.84)\end{array}$ & $\begin{array}{c}\text { PL } \\
(28.43)\end{array}$ & $\begin{array}{c}\mathrm{CA} \\
(23.23)\end{array}$ & $\begin{array}{c}\text { ZA } \\
(20.51)\end{array}$ & $\begin{array}{c}\mathrm{CA} \\
(22.29)\end{array}$ & $\begin{array}{c}\text { CA } \\
(18.76)\end{array}$ \\
\hline 8 & \begin{tabular}{|c|}
$\mathrm{NL}$ \\
$(16.25)$ \\
\end{tabular} & $\begin{array}{c}\mathrm{DE} \\
(11.59) \\
\end{array}$ & $\begin{array}{c}\text { ID } \\
(25.23)\end{array}$ & $\begin{array}{c}\mathrm{DE} \\
(22.06)\end{array}$ & $\begin{array}{c}\text { CA } \\
(27.59)\end{array}$ & $\begin{array}{c}\text { ZA } \\
(26.41)\end{array}$ & $\begin{array}{c}\mathrm{ZA} \\
(20.90)\end{array}$ & $\begin{array}{c}\text { NL } \\
(20.11)\end{array}$ & $\begin{array}{c}\mathrm{KR} \\
(20.86)\end{array}$ & $\begin{array}{c}\text { IN } \\
(16.94)\end{array}$ \\
\hline 9 & \begin{tabular}{|c|}
$\mathrm{CO}$ \\
$(15.58)$
\end{tabular} & $\begin{array}{c}\mathrm{NL} \\
(10.87)\end{array}$ & $\begin{array}{c}\mathrm{NL} \\
(23.68)\end{array}$ & $\begin{array}{c}\mathrm{NL} \\
(21.9)\end{array}$ & $\begin{array}{c}\mathrm{NL} \\
(24.61)\end{array}$ & $\begin{array}{c}\mathrm{DE} \\
(25.6)\end{array}$ & $\begin{array}{c}\mathrm{NL} \\
(17.49)\end{array}$ & $\begin{array}{c}\text { KR } \\
(18.92)\end{array}$ & $\begin{array}{c}\mathrm{DE} \\
(20.8)\end{array}$ & $\begin{array}{c}\mathrm{NL} \\
(13.85)\end{array}$ \\
\hline 10 & $\begin{array}{c}\mathrm{PL} \\
(14.97)\end{array}$ & $\begin{array}{c}\text { IN } \\
(10.13)\end{array}$ & $\begin{array}{c}\mathrm{RU} \\
(21.83)\end{array}$ & $\begin{array}{c}\mathrm{RU} \\
(20.93)\end{array}$ & $\begin{array}{c}\mathrm{CO} \\
(22.26)\end{array}$ & $\begin{array}{c}\mathrm{NL} \\
(24.09)\end{array}$ & $\begin{array}{c}\text { PL } \\
(16.77)\end{array}$ & $\begin{array}{c}\mathrm{CO} \\
(16.53)\end{array}$ & $\begin{array}{c}\mathrm{ZA} \\
(20.76)\end{array}$ & $\begin{array}{c}\text { ZA } \\
(13.77)\end{array}$ \\
\hline & 2009 & 2010 & 2011 & 2012 & 2013 & 2014 & 2015 & 2016 & 2017 & 2018 \\
\hline 1 & $\begin{array}{c}\mathrm{AU} \\
(100)\end{array}$ & $\begin{array}{c}\mathrm{AU} \\
(100)\end{array}$ & $\begin{array}{c}\mathrm{AU} \\
(100)\end{array}$ & $\begin{array}{c}\mathrm{AU} \\
(100)\end{array}$ & $\begin{array}{c}\mathrm{AU} \\
(100)\end{array}$ & $\begin{array}{c}\mathrm{AU} \\
(100)\end{array}$ & $\begin{array}{c}\mathrm{AU} \\
(100)\end{array}$ & $\begin{array}{c}\mathrm{AU} \\
(100)\end{array}$ & $\begin{array}{c}\mathrm{AU} \\
(100)\end{array}$ & $\begin{array}{c}\mathrm{AU} \\
(100)\end{array}$ \\
\hline 2 & $\begin{array}{c}\mathrm{JP} \\
(51.77)\end{array}$ & $\begin{array}{c}J P \\
(53.65)\end{array}$ & $\begin{array}{c}\mathrm{JP} \\
(57.20)\end{array}$ & $\begin{array}{c}\mathrm{JP} \\
(57.91)\end{array}$ & $\begin{array}{c}\mathrm{CN} \\
(61.66)\end{array}$ & $\begin{array}{c}\text { ID } \\
(54.62)\end{array}$ & $\begin{array}{c}\text { ID } \\
(52.63)\end{array}$ & $\begin{array}{c}\mathrm{JP} \\
(46.62)\end{array}$ & $\begin{array}{c}\mathrm{JP} \\
(45.03)\end{array}$ & $\begin{array}{c}\mathrm{JP} \\
(44.06)\end{array}$ \\
\hline 3 & \begin{tabular}{|c|}
$\mathrm{CN}$ \\
$(30.16)$ \\
\end{tabular} & $\begin{array}{c}\text { ID } \\
(45.84)\end{array}$ & $\begin{array}{c}\text { ID } \\
(52.47)\end{array}$ & $\begin{array}{c}\text { ID } \\
(56.51)\end{array}$ & $\begin{array}{c}\text { ID } \\
(59.33) \\
\end{array}$ & $\begin{array}{l}\mathrm{CN} \\
(50) \\
\end{array}$ & $\begin{array}{c}\mathrm{JP} \\
(49.82) \\
\end{array}$ & $\begin{array}{c}\text { ID } \\
(44.59)\end{array}$ & $\begin{array}{c}\text { ID } \\
(42.26) \\
\end{array}$ & $\begin{array}{c}\text { ID } \\
(42.86) \\
\end{array}$ \\
\hline 4 & $\begin{array}{c}\mathrm{RU} \\
(26.4)\end{array}$ & $\begin{array}{c}\mathrm{CN} \\
(42.82)\end{array}$ & $\begin{array}{c}\mathrm{CN} \\
(42.18)\end{array}$ & $\begin{array}{c}\mathrm{CN} \\
(51.86)\end{array}$ & $\begin{array}{c}\mathrm{JP} \\
(54.4)\end{array}$ & $\begin{array}{c}\mathrm{JP} \\
(49.42)\end{array}$ & $\begin{array}{c}\text { IN } \\
(42.46)\end{array}$ & $\begin{array}{c}\mathrm{CN} \\
(42.57)\end{array}$ & $\begin{array}{c}\mathrm{CN} \\
(41.47)\end{array}$ & $\begin{array}{c}\mathrm{CN} \\
(40.04)\end{array}$ \\
\hline 5 & $\begin{array}{c}\text { US } \\
(24.57)\end{array}$ & $\begin{array}{c}\text { IN } \\
(30.48)\end{array}$ & $\begin{array}{c}\text { US } \\
(37.04)\end{array}$ & $\begin{array}{c}\text { US } \\
(37.67)\end{array}$ & $\begin{array}{c}\text { IN } \\
(36.27)\end{array}$ & $\begin{array}{c}\mathrm{IN} \\
(40.46)\end{array}$ & $\begin{array}{c}\mathrm{CN} \\
(36.84)\end{array}$ & $\begin{array}{c}\text { IN } \\
(38.18)\end{array}$ & $\begin{array}{c}\text { IN } \\
(36.95)\end{array}$ & $\begin{array}{c}\text { IN } \\
(39.24)\end{array}$ \\
\hline 6 & $\begin{array}{c}\mathrm{KR} \\
(21.38)\end{array}$ & $\begin{array}{c}\text { US } \\
(29.72)\end{array}$ & $\begin{array}{c}\mathrm{IN} \\
(34.36)\end{array}$ & $\begin{array}{c}\text { IN } \\
(34.42)\end{array}$ & $\begin{array}{c}\mathrm{RU} \\
(33.16)\end{array}$ & $\begin{array}{c}\mathrm{RU} \\
(36.13)\end{array}$ & $\begin{array}{c}\mathrm{RU} \\
(35.44)\end{array}$ & $\begin{array}{c}\mathrm{RU} \\
(31.69)\end{array}$ & $\begin{array}{c}\mathrm{RU} \\
(31.87)\end{array}$ & $\begin{array}{c}\mathrm{RU} \\
(34.81)\end{array}$ \\
\hline 7 & $\begin{array}{c}\text { IN } \\
(20.19)\end{array}$ & $\begin{array}{c}\text { KR } \\
(28.21)\end{array}$ & $\begin{array}{c}\text { KR } \\
(31.89)\end{array}$ & $\begin{array}{c}\mathrm{RU} \\
(33.49)\end{array}$ & $\begin{array}{c}\text { US } \\
(32.12)\end{array}$ & $\begin{array}{c}\text { US } \\
(27.83)\end{array}$ & $\begin{array}{c}\text { KR } \\
(27.05)\end{array}$ & $\begin{array}{c}\text { KR } \\
(26.28)\end{array}$ & $\begin{array}{c}\mathrm{KR} \\
(27.94)\end{array}$ & $\begin{array}{c}\text { KR } \\
(26.76)\end{array}$ \\
\hline 8 & $\begin{array}{c}\mathrm{CO} \\
(17.43)\end{array}$ & $\begin{array}{c}\text { RU } \\
(25.19)\end{array}$ & $\begin{array}{c}\mathrm{RU} \\
(27.57)\end{array}$ & $\begin{array}{c}\text { KR } \\
(29.30)\end{array}$ & $\begin{array}{c}\mathrm{KR} \\
(27.72)\end{array}$ & $\begin{array}{c}\mathrm{KR} \\
(27.54)\end{array}$ & $\begin{array}{c}\text { US } \\
(23.05)\end{array}$ & $\begin{array}{c}\text { US } \\
(17.77)\end{array}$ & $\begin{array}{c}\text { US } \\
(22.48)\end{array}$ & $\begin{array}{c}\text { US } \\
(25.35)\end{array}$ \\
\hline 9 & $\begin{array}{c}\text { CA } \\
(17.33) \\
\end{array}$ & $\begin{array}{c}\text { CA } \\
(17.81)\end{array}$ & $\begin{array}{c}\text { CA } \\
(19.07)\end{array}$ & $\begin{array}{c}\mathrm{CO} \\
(18.16)\end{array}$ & $\begin{array}{c}\mathrm{CO} \\
(17.33)\end{array}$ & $\begin{array}{c}\mathrm{CO} \\
(19.68)\end{array}$ & $\begin{array}{l}\mathrm{CO} \\
(16)\end{array}$ & $\begin{array}{c}\mathrm{CO} \\
(15.68)\end{array}$ & $\begin{array}{c}\mathrm{CO} \\
(15.75)\end{array}$ & $\begin{array}{c}\text { CA } \\
(13.3)\end{array}$ \\
\hline 10 & $\begin{array}{c}\mathrm{ZA} \\
(14.28)\end{array}$ & $\begin{array}{c}\mathrm{ZA} \\
(15.34)\end{array}$ & $\begin{array}{c}\mathrm{CO} \\
(17.28)\end{array}$ & $\begin{array}{c}\mathrm{CA} \\
(17.65)\end{array}$ & $\begin{array}{c}\mathrm{ZA} \\
(15.83)\end{array}$ & $\begin{array}{c}\mathrm{NL} \\
(16.16)\end{array}$ & $\begin{array}{c}\mathrm{ZA} \\
(15.02)\end{array}$ & $\begin{array}{c}\mathrm{ZA} \\
(13.99)\end{array}$ & $\begin{array}{c}\mathrm{ZA} \\
(13.97)\end{array}$ & $\begin{array}{c}\mathrm{CO} \\
(13.24)\end{array}$ \\
\hline
\end{tabular}




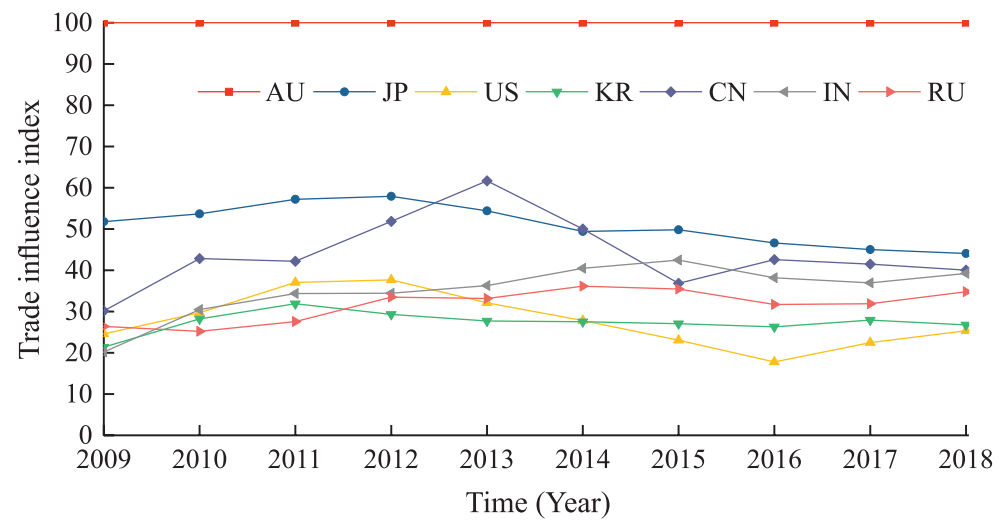

Figure 9. Evolution of dominant trade leading countries' trade influence index

Evolution of the ranking of trade hub: The coal trading hub is a crucial link in the circulation of coal, and it is also an important component of the coal international transportation network. Different from the trade leading countries, trade hub countries put particular emphasis on the transfer transportation capacity of the coal. Based on the 1999-2018 international coal trade data, the betweenness centrality of each participating country is calculated to measure the coal transfer capacity of each country, and the major trading hub countries are given in Table 5. A trade hub must not only have a high degree of centrality, but also have a certain degree of stability. As shown in Table 5, these five countries, including the United States, South Africa, India, the United Kingdom, and Russia, have possessed stable and high-ranking betweenness centrality since 2009. Therefore, they are recognized as core coal international hub countries. As shown in Figure 10, the betweenness centrality of a core hub country fluctuates within a certain range. Their betweenness centrality declined obviously between 2014 and 2016, but then recovered. The United States and South Africa both are the most important coal trading hubs, and their betweenness centrality are significantly higher than others. India, the United Kingdom, and Russia have little difference in their betweenness centrality, but Russia's role as a trading hub in recent years has become more and more important. As a major coal trade leading country, Russia, by virtue of its geographical advantage that it spans the Eurasia continent, has a solid foundation to become a crucially important trade hub.

Table 5. Trade hubs' betweenness centrality in 1999-2018

\begin{tabular}{|c|c|c|c|c|c|c|c|c|c|c|}
\hline & 1999 & 2000 & 2001 & 2002 & 2003 & 2004 & 2005 & 2006 & 2007 & 2008 \\
\hline \multirow{2}{*}{1} & US & AU & US & ZA & US & US & US & US & US & US \\
& $(0.057)$ & $(0.042)$ & $(0.084)$ & $(0.094)$ & $(0.089)$ & $(0.089)$ & $(0.104)$ & $(0.097)$ & $(0.119)$ & $(0.113)$ \\
\hline \multirow{2}{*}{2} & RU & CO & UK & US & ZA & ZA & ZA & CN & ZA & ZA \\
& $(0.050)$ & $(0.039)$ & $(0.058)$ & $(0.077)$ & $(0.065)$ & $(0.075)$ & $(0.080)$ & $(0.085)$ & $(0.098)$ & $(0.094)$ \\
\hline \multirow{2}{*}{3} & UK & ID & RU & CN & CN & DE & CN & ZA & CN & CN \\
& $(0.033)$ & $(0.035)$ & $(0.046)$ & $(0.066)$ & $(0.057)$ & $(0.048)$ & $(0.073)$ & $(0.083)$ & $(0.074)$ & $(0.069)$ \\
\hline \multirow{2}{*}{4} & CO & CN & ID & UK & UK & RU & DE & DE & DE & DE \\
& $(0.031)$ & $(0.034)$ & $(0.038)$ & $(0.048)$ & $(0.055)$ & $(0.045)$ & $(0.044)$ & $(0.040)$ & $(0.045)$ & $(0.043)$ \\
\hline
\end{tabular}


End of Table 5

\begin{tabular}{|c|c|c|c|c|c|c|c|c|c|c|}
\hline & 1999 & 2000 & 2001 & 2002 & 2003 & 2004 & 2005 & 2006 & 2007 & 2008 \\
\hline 5 & $\begin{array}{c}\text { TR } \\
(0.024)\end{array}$ & $\begin{array}{c}\mathrm{DE} \\
(0.029)\end{array}$ & $\begin{array}{c}\mathrm{CN} \\
(0.038)\end{array}$ & $\begin{array}{c}\mathrm{RU} \\
(0.046)\end{array}$ & $\begin{array}{c}\mathrm{DE} \\
(0.052)\end{array}$ & $\begin{array}{c}\mathrm{PL} \\
(0.038)\end{array}$ & $\begin{array}{c}\mathrm{RU} \\
(0.040)\end{array}$ & $\begin{array}{c}\mathrm{RU} \\
(0.038)\end{array}$ & $\begin{array}{c}\text { UK } \\
(0.036)\end{array}$ & $\begin{array}{c}\text { IN } \\
(0.039)\end{array}$ \\
\hline 6 & $\begin{array}{c}\mathrm{AU} \\
(0.022)\end{array}$ & $\begin{array}{c}\text { IT } \\
(0.027)\end{array}$ & $\begin{array}{c}\mathrm{AU} \\
(0.032)\end{array}$ & $\begin{array}{c}\mathrm{AU} \\
(0.043)\end{array}$ & $\begin{array}{c}\text { RU } \\
(0.048)\end{array}$ & $\begin{array}{c}\text { UK } \\
(0.038)\end{array}$ & $\begin{array}{c}\text { UK } \\
(0.028)\end{array}$ & $\begin{array}{c}\text { IN } \\
(0.026)\end{array}$ & $\begin{array}{c}\text { RU } \\
(0.035)\end{array}$ & $\begin{array}{c}\text { UK } \\
(0.037)\end{array}$ \\
\hline 7 & $\begin{array}{c}\text { ID } \\
(0.019)\end{array}$ & $\begin{array}{c}\mathrm{NL} \\
(0.024)\end{array}$ & $\begin{array}{c}\mathrm{CO} \\
(0.030)\end{array}$ & $\begin{array}{c}\text { LB } \\
(0.043)\end{array}$ & $\begin{array}{c}\mathrm{AU} \\
(0.041)\end{array}$ & $\begin{array}{c}\mathrm{CN} \\
(0.036)\end{array}$ & $\begin{array}{c}\mathrm{AU} \\
(0.026)\end{array}$ & $\begin{array}{c}\mathrm{AU} \\
(0.026)\end{array}$ & $\begin{array}{c}\text { IN } \\
(0.031)\end{array}$ & $\begin{array}{c}\text { LB } \\
(0.034)\end{array}$ \\
\hline 8 & $\begin{array}{c}\text { PL } \\
(0.018)\end{array}$ & $\begin{array}{c}\text { FR } \\
(0.020)\end{array}$ & $\begin{array}{c}\text { TR } \\
(0.026)\end{array}$ & $\begin{array}{c}\mathrm{DE} \\
(0.035)\end{array}$ & $\begin{array}{c}\text { IT } \\
(0.027)\end{array}$ & $\begin{array}{c}\text { IN } \\
(0.030)\end{array}$ & $\begin{array}{c}\text { IN } \\
(0.017)\end{array}$ & $\begin{array}{c}\text { UK } \\
(0.025)\end{array}$ & $\begin{array}{c}\text { TR } \\
(0.027)\end{array}$ & $\begin{array}{c}\mathrm{AU} \\
(0.028)\end{array}$ \\
\hline 9 & $\begin{array}{c}\text { IT } \\
(0.016)\end{array}$ & $\begin{array}{c}\text { LB } \\
(0.018)\end{array}$ & $\begin{array}{c}\mathrm{NL} \\
(0.024)\end{array}$ & $\begin{array}{c}\text { IT } \\
(0.030)\end{array}$ & $\begin{array}{c}\mathrm{CO} \\
(0.024)\end{array}$ & $\begin{array}{c}\mathrm{AU} \\
(0.027)\end{array}$ & $\begin{array}{c}\text { IT } \\
(0.016)\end{array}$ & $\begin{array}{c}\text { IT } \\
(0.021)\end{array}$ & $\begin{array}{c}\text { IT } \\
(0.026)\end{array}$ & $\begin{array}{c}\mathrm{CO} \\
(0.027)\end{array}$ \\
\hline 10 & $\begin{array}{c}\mathrm{CN} \\
(0.014)\end{array}$ & $\begin{array}{c}\mathrm{BE} \\
(0.015)\end{array}$ & $\begin{array}{c}\text { LB } \\
(0.023)\end{array}$ & $\begin{array}{c}\text { TR } \\
(0.022)\end{array}$ & $\begin{array}{c}\mathrm{BE} \\
(0.019)\end{array}$ & $\begin{array}{c}\text { IT } \\
(0.026)\end{array}$ & $\begin{array}{c}\mathrm{BE} \\
(0.015)\end{array}$ & $\begin{array}{c}\text { FR } \\
(0.020)\end{array}$ & $\begin{array}{c}\text { LB } \\
(0.026)\end{array}$ & $\begin{array}{c}\mathrm{NZ} \\
(0.025)\end{array}$ \\
\hline & 2009 & 2010 & 2011 & 2012 & 2013 & 2014 & 2015 & 2016 & 2017 & 2018 \\
\hline 1 & $\begin{array}{c}\text { US } \\
(0.133)\end{array}$ & $\begin{array}{c}\text { US } \\
(0.121)\end{array}$ & $\begin{array}{c}\text { US } \\
(0.099)\end{array}$ & $\begin{array}{c}\text { US } \\
(0.130)\end{array}$ & $\begin{array}{c}\text { US } \\
(0.104)\end{array}$ & $\begin{array}{c}\text { US } \\
(0.126)\end{array}$ & $\begin{array}{c}\mathrm{ZA} \\
(0.057) \\
\end{array}$ & $\begin{array}{c}\text { ZA } \\
(0.062)\end{array}$ & $\begin{array}{c}\mathrm{ZA} \\
(0.120) \\
\end{array}$ & $\begin{array}{c}\text { US } \\
(0.101)\end{array}$ \\
\hline 2 & $\begin{array}{c}\text { ZA } \\
(0.103) \\
\end{array}$ & $\begin{array}{c}\text { ZA } \\
(0.086) \\
\end{array}$ & $\begin{array}{c}\text { ZA } \\
(0.092) \\
\end{array}$ & $\begin{array}{c}\mathrm{ZA} \\
(0.110) \\
\end{array}$ & $\begin{array}{c}\text { ZA } \\
(0.093) \\
\end{array}$ & $\begin{array}{c}\mathrm{ZA} \\
(0.093) \\
\end{array}$ & $\begin{array}{c}\text { US } \\
(0.057) \\
\end{array}$ & $\begin{array}{c}\text { US } \\
(0.061)\end{array}$ & $\begin{array}{c}\text { US } \\
(0.105) \\
\end{array}$ & $\begin{array}{c}\text { ZA } \\
(0.093) \\
\end{array}$ \\
\hline 3 & $\begin{array}{c}\mathrm{CN} \\
(0.041)\end{array}$ & $\begin{array}{c}\mathrm{CN} \\
(0.052)\end{array}$ & $\begin{array}{c}\text { IN } \\
(0.057)\end{array}$ & $\begin{array}{c}\text { LB } \\
(0.047)\end{array}$ & $\begin{array}{c}\text { UK } \\
(0.053)\end{array}$ & $\begin{array}{c}\mathrm{RU} \\
(0.043)\end{array}$ & $\begin{array}{c}\text { RU } \\
(0.033)\end{array}$ & $\begin{array}{c}\mathrm{CN} \\
(0.036)\end{array}$ & $\begin{array}{c}\mathrm{RU} \\
(0.083)\end{array}$ & $\begin{array}{c}\mathrm{RU} \\
(0.090)\end{array}$ \\
\hline 4 & $\begin{array}{c}\text { LB } \\
(0.041)\end{array}$ & $\begin{array}{c}\mathrm{RU} \\
(0.039)\end{array}$ & $\begin{array}{c}\text { UK } \\
(0.047)\end{array}$ & $\begin{array}{c}\mathrm{CN} \\
(0.045)\end{array}$ & $\begin{array}{c}\mathrm{CN} \\
(0.050)\end{array}$ & $\begin{array}{c}\text { UK } \\
(0.043)\end{array}$ & $\begin{array}{c}\mathrm{CN} \\
(0.027)\end{array}$ & $\begin{array}{c}\mathrm{RU} \\
(0.025)\end{array}$ & $\begin{array}{c}\text { UK } \\
(0.051)\end{array}$ & $\begin{array}{c}\text { TR } \\
(0.035)\end{array}$ \\
\hline 5 & $\begin{array}{c}\text { IN } \\
(0.036)\end{array}$ & $\begin{array}{c}\text { UK } \\
(0.037)\end{array}$ & $\begin{array}{c}\text { LB } \\
(0.045)\end{array}$ & $\begin{array}{c}\text { UA } \\
(0.041)\end{array}$ & $\begin{array}{c}\text { LB } \\
(0.038)\end{array}$ & $\begin{array}{c}\mathrm{DE} \\
(0.041)\end{array}$ & $\begin{array}{c}\text { UK } \\
(0.022)\end{array}$ & $\begin{array}{c}\text { UK } \\
(0.021)\end{array}$ & $\begin{array}{c}\text { TR } \\
(0.043)\end{array}$ & $\begin{array}{c}\text { UK } \\
(0.033)\end{array}$ \\
\hline 6 & $\begin{array}{c}\text { UK } \\
(0.034)\end{array}$ & $\begin{array}{c}\text { UA } \\
(0.033)\end{array}$ & $\begin{array}{c}\mathrm{RU} \\
(0.039)\end{array}$ & $\begin{array}{c}\text { IN } \\
(0.040)\end{array}$ & $\begin{array}{c}\mathrm{RU} \\
(0.035)\end{array}$ & $\begin{array}{c}\mathrm{CN} \\
(0.039)\end{array}$ & $\begin{array}{c}\mathrm{AU} \\
(0.018)\end{array}$ & $\begin{array}{c}\text { IN } \\
(0.016)\end{array}$ & $\begin{array}{c}\mathrm{AU} \\
(0.033)\end{array}$ & $\begin{array}{c}\mathrm{NL} \\
(0.030)\end{array}$ \\
\hline 7 & $\begin{array}{c}\mathrm{DE} \\
(0.028)\end{array}$ & $\begin{array}{c}\text { ID } \\
(0.030)\end{array}$ & $\begin{array}{c}\text { CA } \\
(0.038)\end{array}$ & $\begin{array}{c}\text { UK } \\
(0.038)\end{array}$ & $\begin{array}{c}\mathrm{DE} \\
(0.034)\end{array}$ & $\begin{array}{c}\text { ES } \\
(0.030)\end{array}$ & $\begin{array}{c}\text { IT } \\
(0.014)\end{array}$ & $\begin{array}{c}\mathrm{DE} \\
(0.014)\end{array}$ & $\begin{array}{c}\text { LB } \\
(0.033)\end{array}$ & $\begin{array}{c}\text { IN } \\
(0.024)\end{array}$ \\
\hline 8 & $\begin{array}{c}\mathrm{RU} \\
(0.026)\end{array}$ & $\begin{array}{c}\text { IN } \\
(0.030)\end{array}$ & $\begin{array}{c}\mathrm{CN} \\
(0.033)\end{array}$ & $\begin{array}{c}\mathrm{RU} \\
(0.031)\end{array}$ & $\begin{array}{c}\text { UA } \\
(0.030)\end{array}$ & $\begin{array}{c}\mathrm{AU} \\
(0.029)\end{array}$ & $\begin{array}{c}\text { TR } \\
(0.013)\end{array}$ & $\begin{array}{c}\mathrm{NZ} \\
(0.013)\end{array}$ & $\begin{array}{c}\text { IN } \\
(0.026)\end{array}$ & $\begin{array}{c}\text { LB } \\
(0.023)\end{array}$ \\
\hline 9 & $\begin{array}{c}\mathrm{AU} \\
(0.025)\end{array}$ & $\begin{array}{c}\text { TR } \\
(0.025)\end{array}$ & $\begin{array}{c}\text { UA } \\
(0.033)\end{array}$ & $\begin{array}{c}\mathrm{CO} \\
(0.030) \\
\end{array}$ & $\begin{array}{c}\text { IN } \\
(0.028) \\
\end{array}$ & $\begin{array}{c}\text { LB } \\
(0.029) \\
\end{array}$ & $\begin{array}{c}\text { IN } \\
(0.012) \\
\end{array}$ & $\begin{array}{c}\text { ES } \\
(0.012) \\
\end{array}$ & $\begin{array}{c}\text { NL } \\
(0.025) \\
\end{array}$ & $\begin{array}{c}\mathrm{CN} \\
(0.021)\end{array}$ \\
\hline 10 & $\begin{array}{c}\text { TR } \\
(0.025)\end{array}$ & $\begin{array}{c}\mathrm{BE} \\
(0.024)\end{array}$ & $\begin{array}{c}\mathrm{DE} \\
(0.030)\end{array}$ & $\begin{array}{c}\mathrm{NZ} \\
(0.028)\end{array}$ & $\begin{array}{c}\mathrm{CO} \\
(0.028)\end{array}$ & $\begin{array}{c}\text { IN } \\
(0.028)\end{array}$ & $\begin{array}{c}\text { ES } \\
(0.011)\end{array}$ & $\begin{array}{c}\text { TR } \\
(0.012)\end{array}$ & $\begin{array}{c}\text { IT } \\
(0.024)\end{array}$ & $\begin{array}{c}\text { IT } \\
(0.018)\end{array}$ \\
\hline
\end{tabular}

With the development of the coal trade, the gradual coal consumption among countries prompts an increase of more economical and convenient alternatives. Some large trading countries are influenced by the environmental protection and politics, causing their influence has decreased. In some ways, their trading positions are being overtaken by some developing countries. However, Australia and the United States still maintain strong positions based on their convenient transportation and sound resources. The emerging coal trading countries should expand new markets, adopt flexible measures and develop bilateral trade instead of direct competition with traditional coal powers. It is essential for each coal trading country to actively consolidate the relationship with traditional coal powers, and develop direct trading contacts with the emerging coal trading countries. 


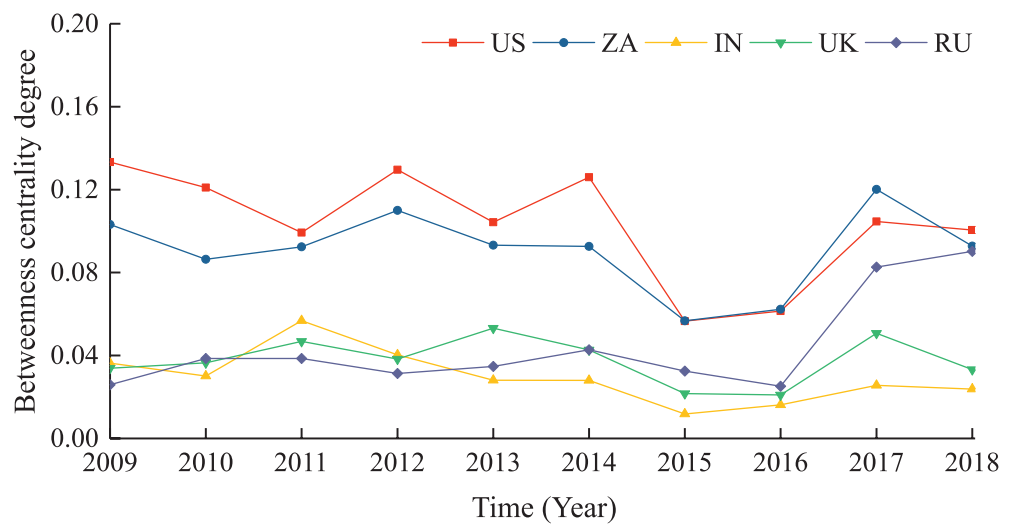

Figure 10. Evolution of the ranking of major trading hubs

\section{Countermeasures}

International trade is full of cooperation and competition, and no country can be exception. For every country, there are specific factors that enable it to gain an advantage in the international trade competition. Whether the international coal trade is prosperous and stable or not is closely related to the trade competitiveness of each participating country. The theory of competitive advantage proposed by Michael Porter can be used to analyze the specific production of a specific country or region compared with other countries or regions in the same domain and evaluate their corresponding economic benefits and competitive advantages, especially industry innovation and the elevating capacity, widely applied in the competitive analyzes of the industry, agriculture and service industry. In order to enhance the trade competitiveness, according to Michael Porter's theory of competitive advantage, the countermeasures of each country to gain competitive advantage are analyzed.

In the long run of coal demand, thanks to the growing international energy demand, the scale of the international coal trade kept growing steadily and trade activities remained increasingly active from 1999 to 2018, although the global market faced the long-term challenges of traditional energy sources, such as oil and natural gas, and strong competition from new energy sources, such as wind, nuclear and solar energy. The ability of each country to form competitive advantage in the international coal market is critical to ensure energy security and economic development. Michael Porter believes that a complete supporting industry is conducive to forming a competitive advantage. On the basis of the existing coal industry, the integration and development of a complete coal industry chain is conducive to forming a competitive advantage under this economic background that the international coal trade maintains steady development. The relevant countries should take coal mining as the basis, focusing on supporting the development of related industries, and make a part of the industrial chain grow big and strong, which can quickly form their competitive advantages.

From the perspective of the evolution of trade relations, the overall trend of trade development tends to be stable. The international coal trade has formed a relatively strong trading group over time. Countries should follow this trend and actively join the formed trading group or establish clear regional trade organizations. For net coal importers, firstly, by expanding 
its own internal demand, they can consolidate its position in the trading group. Secondly, they should proactively track major coal consumers for a long time and use this as the basis for adjusting coal trade. Finally, it is necessary to strengthen political, economic and cultural exchanges with major exporting countries to stabilize import sources and reduce unnecessary trade risks. For net coal exporters, firstly, developing their internal demand can effectively avoid export dependence. Secondly, upgrading technological means to reduce the cost of coal production can help to form a price advantage. And finally, their products should be improved to meet the complicated needs, taking into account differences in demand of the importers.

Trade flows spread toward an unbalanced state in recent years. From the perspective of the distribution of trade networks, there is a large difference in trade flows between various countries. This difference has become more pronounced in recent years, and future trade will be more unbalanced. Michael Porter believes that the essence of trade flow is the flow of production factors and the imbalance in trade flow is equal to the imbalance in the distribution of production factors. He divides the production factors into primary and advanced ones and points out that the advanced are more important for a country to obtain competitive advantages, including the environment, technology, and information factor. From the perspective of environmental factors, Australia and the United States have adequate coal resources, high coal quality and excellent mining environment. From the perspective of technical factors, Australia and the United States utilized and developed the coal earlier than others and have better access to the advanced mining technology in the world now. From the perspective of informational factors, Australia and the United States have established large-scale and long-term regional cooperation organizations, and within which information can be exchanged frequently and conveniently. The above-mentioned countries are traditional coal trading powers, who have strong competitive advantages, sufficient financial resources, and the ability to continue to develop advanced technologies, maintain organizational development, and further consolidate their competitive advantages. Both of the two powers have great impact on the flow of coal trade. For competitors, firstly, emerging exporting countries including India and Indonesia should take full advantage of their human resources advantages, accelerate their pace to master the advanced technologies, and develop the qualified professionals in this field. Secondly, some major trade transit countries, including Russia, which are also large net coal exporters, should integrate their intra-regional trade and expand their information advantages. Finally, such coal net importers as represented by China should take full advantage of the Belt and Road policy to diversify coal suppliers to avoid monopoly, explore the transit transportation capacity brought by the excellent infrastructure, undertake missions of the trade center, and strive to become the core coal hub countries in their region.

From the perspective of major coal participating countries, the international coal trade has not been affected much by the financial crisis. Even in 2008 and 2009, when the financial crisis had the greatest impact, international coal trade continued to grow steadily in terms of trade scale and the number of participating countries. Coal, as a traditional primary energy source, is consumed in a huge volume. And after long-term development, coal consuming countries are basically fixed, so the total amount of coal consumption has not changed significantly. The degree of reciprocity and equilibrium in coal trade has declined somewhat, but the trend is smooth and it can be considered as the result of competition between coal and other alternative energy sources. Michael Porter believes that opportunities are uncontrollable and the impact of 
government policies cannot be ignored. The United States took the lead in launching a series of trade frictions against China around 2015, and various trade indicators have undergone significant changes since then. This change is reflected in the decrease in cooperation between countries, the increase in the concentration of coal trade, the obvious increase in independent trade groups. Most trade tends to be carried out within groups, the number of trading partners of some countries has decreased significantly, and the pivotal role of major coal trading countries has been reduced. Data shows that the above situation has partially improved since 2017, but the negative impact of trade frictions on the international coal trade is far from eliminated. The trade dispute reminded all countries that energy security is related to the development of countries. For most countries, firstly, single energy dependence should be avoided, and more types of alternative energy sources should be developed. Secondly, it is inevitable to upgrade technology and transform industries to reduce coal consumption. Finally, it is very necessary to expand energy channels and increase trade influence. Generally speaking, the international coal market, which is in an active state of competition and has clear institutional norms, is more able to withstand the impact of policy changes.

\section{Conclusions}

Through the multi-faceted analysis of the international coal trade, we can clearly realize the scale and trade distribution of the international coal market. Through the analysis of the various evolutionary characteristics of the international coal trade, we can understand the degree of aggregation and equilibrium of trade. By analyzing the major trade participating countries, we can find the core countries in coal trade and the characteristics that affect their changes. Although new trading powers are emerging, it is still difficult to challenge the dominant position of traditional trading powers such as Australia and the United States. Finally, combined with Michael Porter's theory of competitive advantage, strategies and suggestions to enhance trade competitiveness were put forward for each participating country. All countries should identify their own positioning, deepen the construction of industrial chain, fully tap internal demand and reduce external dependence. Practice shows that a stable alliance is beneficial to prevent emergencies, and strengthening international cooperation is very important for every country.

The complex network method simplifies the complex international trade and analyzes the trade relations between countries from a macro perspective. Because of this, the consideration of some more complicated influencing factors such as the environment, policies, and human geography is not yet complete. Therefore, there is still room for further in-depth research on the dynamic evolution of the international coal trade.

\section{Acknowledgements}

The authors acknowledge the learned reviewers for their valuable suggestions in enriching the quality of the paper. The authors acknowledge my friend MA Lin for her selfless contribution to the paper. The authors also acknowledge the support and cooperation provided by the bossiness school of Changzhou University, the school of management of China University 
of Mining and Technology, Beijing and the National Natural Science Foundation of China (Grant No. 61471362).

\section{Funding}

This work was supported by the the National Natural Science Foundation of China under Grant No. 61471362.

\section{Author contributions}

Both authors initiated this research and a manuscript. Chen Xiaoci and Tan Zhanglu proposed the study goal. Chen Xiaoci and Li Siwen was responsible for data analysis and conducted literature search.

\section{Disclosure statement}

Both authors don't have any competing financial, professional, or personal interests with other parties.

\section{References}

Barabási, A. L., \& Albert, R. (1999). Emergence of scaling in random networks. Science, 286(5439), 509-512. https://doi.org/10.1126/science.286.5439.509

Bhattacharya, K., Mukherjee, G., Saramäki, J., Kaski, K., \& Manna, S. S. (2008). The international trade network: weighted network analysis and modelling. Journal of Statistical Mechanics: Theory and Experiment, 2008(02), P02002. https://doi.org/10.1088/1742-5468/2008/02/P02002

BP. (2019, June 11). BP Statistical Review of World Energy. https://www.bp.com/en/global/corporate/ news-and-insights/press-releases/bp-statistical-review-of-world-energy-2019.html

Chen, J., Xie, Q., Shahbaz, M., Song, M., \& Wu, Y. (2021). The fossil energy trade relations among BRICS countries. Energy, 217, 119383. https://doi.org/10.1016/j.energy.2020.119383

Cronshaw, I. (2015). World Energy Outlook 2014 projections to 2040: Natural gas and coal trade, and the role of China. Australian Journal of Agricultural and Resource Economics, 59(4), 571-585. https://doi.org/10.1111/1467-8489.12120

Gao, C., Su, B., Sun, M., Zhang, X., \& Zhang, Z. (2018). Interprovincial transfer of embodied primary energy in China: A complex network approach. Applied Energy, 215, 792-807. https://doi.org/10.1016/j.apenergy.2018.02.075

Guan, Q., \& An, H. (2017). The exploration on the trade preferences of cooperation partners in four energy commodities' international trade: Crude oil, coal, natural gas and photovoltaic. Applied Energy, 203, 154-163. https://doi.org/10.1016/j.apenergy.2017.06.026

Guimera, R., Mossa, S., Turtschi, A., \& Amaral, L. N. (2005). The worldwide air transportation network: Anomalous centrality, community structure, and cities' global roles. Proceedings of the National Academy of Sciences, 102(22), 7794-7799. https://doi.org/10.1073/pnas.0407994102

Hauenstein, C., \& Holz, F. (2021). The US coal sector between shale gas and renewables: Last resort coal exports? Energy Policy, 149, 112097. https://doi.org/10.1016/j.enpol.2020.112097 
Hu, X., Wang, C., Lim, M. K., \& Koh, S. L. (2020). Characteristics and community evolution patterns of the international scrap metal trade. Journal of Cleaner Production, 243, 118576. https://doi.org/10.1016/j.jclepro.2019.118576

Hye, Q. M. A., \& Lau, W. Y. (2015). Trade openness and economic growth: empirical evidence from India. Journal of Business Economics and Management, 16(1), 188-205. https://doi.org/10.3846/16111699.2012.720587

Long, T., Pan, H., Dong, C., Qin, T., \& Ma, P. (2019). Exploring the competitive evolution of global wood forest product trade based on complex network analysis. Physica A: Statistical Mechanics and Its Applications, 525, 1224-1232. https://doi.org/10.1016/j.physa.2019.04.187

Malighetti, P., Martini, G., Redondi, R., \& Scotti, D. (2019). Air transport networks of global integrators in the more liberalized Asian air cargo industry. Transport Policy, 80, 12-23. https://doi.org/10.1016/j.tranpol.2019.04.021

Newman, M. E. (2002). Assortative mixing in networks. Physical Review Letters, 89(20), 208701. https://doi.org/10.1103/PhysRevLett.89.208701

Semanur, S., Hüseyin, T., \& Halil, Ö. (2020). An alternative view to the global coal trade: Complex network approach. Studies in Business and Economics, 15(1), 270-288. https://doi.org/10.2478/sbe-2020-0020

Strogatz, S. H. (2001). Exploring complex networks. Nature, 410(6825), 268-276. https://doi.org/10.1038/35065725

Torres, N., Afonso, O., \& Soares, I. (2013). Natural resources, wage growth and institutions - a panel approach. The World Economy, 36(5), 661-687. https://doi.org/10.1111/twec.12023

Umar, M., Ji, X., Kirikkaleli, D., Shahbaz, M., \& Zhou, X. (2020). Environmental cost of natural resources utilization and economic growth: Can China shift some burden through globalization for sustainable development? Sustainable Development, 28(6), 1678-1688. https://doi.org/10.1002/sd.2116

Wang, W., \& Li, Z. (2019). The evolution of China's interregional coal trade network, 1997-2016. Physica A: Statistical Mechanics and its Applications, 536, 120974.

https://doi.org/10.1016/j.physa.2019.04.210

Wang, X., Yao, M., Li, J., Ge, J., Wei, W., Wu, B., \& Zhang, M. (2019). Global embodied rare earths flows and the outflow paths of China's embodied rare earths: Combining multi-regional input-output analysis with the complex network approach. Journal of Cleaner Production, 216, 435-445. https://doi.org/10.1016/j.jclepro.2018.12.312

Watts, D. J., \& Strogatz, S. H. (1998). Collective dynamics of "small-world" networks. Nature, 393, 440-442. https://doi.org/10.1038/30918

Wu, X. F., \& Chen, G. Q. (2018). Coal use embodied in globalized world economy: From source to sink through supply chain. Renewable and Sustainable Energy Reviews, 81, 978-993. https://doi.org/10.1016/j.rser.2017.08.018

Xia, X. H., Chen, B., Wu, X. D., Hu, Y., Liu, D. H., \& Hu, C. Y. (2017). Coal use for world economy: Provision and transfer network by multi-region input-output analysis. Journal of Cleaner Production, 143, 125-144. https://doi.org/10.1016/j.jclepro.2016.12.142

Zhang, Z., Wang, J., \& Li, B. (2019). Determining the influence factors of soil organic carbon stock in opencast coal-mine dumps based on complex network theory. Catena, 173, 433-444. https://doi.org/10.1016/j.catena.2018.10.030

Zhong, W., An, H., Shen, L., Dai, T., Fang, W., Gao, X., \& Dong, D. (2017). Global pattern of the international fossil fuel trade: The evolution of communities. Energy, 123, 260-270. https://doi.org/10.1016/j.energy.2017.02.033

Zhong, W., Dai, T., Wang, G., Li, Q., Li, D., Liang, L., \& Jiang, M. (2018). Structure of international iron flow: Based on substance flow analysis and complex network. Resources, Conservation and Recycling, 136, 345-354. https://doi.org/10.1016/j.resconrec.2018.05.006 